\title{
Long-term monitoring of persistent organic pollutants (POPs) at the Norwegian Troll station in Dronning Maud Land, Antarctica
}

\author{
R. Kallenborn ${ }^{1,2}$, K. Breivik ${ }^{1,3}$, S. Eckhardt ${ }^{1}$, C. R. Lunder $^{1}$, S. Manø ${ }^{1}$, M. Schlabach ${ }^{1}$, and A. Stohl ${ }^{1}$ \\ ${ }^{1}$ Norwegian Institute for Air Research (NILU), Kjeller, Norway \\ ${ }^{2}$ Norwegian University of Life Sciences, Department of Chemistry, Biotechnology and Food Sciences (IKBM), Ås, Norway \\ ${ }^{3}$ University of Oslo, Department of Chemistry, Oslo, Norway
}

Correspondence to: R. Kallenborn (roland.kallenborn@umb.no)

Received: 27 September 2012 - Published in Atmos. Chem. Phys. Discuss.: 8 March 2013

Revised: 7 June 2013 - Accepted: 10 June 2013 - Published: 23 July 2013

\begin{abstract}
A first long-term monitoring of selected persistent organic pollutants (POPs) in Antarctic air has been conducted at the Norwegian research station Troll (Dronning Maud Land). As target contaminants 32 PCB congeners, $\alpha$ - and $\gamma$-hexachlorocyclohexane (HCH), trans- and cis-chlordane, trans- and cis-nonachlor, $p, p^{\prime}-$ and $o, p$-DDT, DDD, DDE as well as hexachlorobenzene (HCB) were selected. The monitoring program with weekly samples taken during the period 2007-2010 was coordinated with the parallel program at the Norwegian Arctic monitoring site (Zeppelin mountain, Ny-Ålesund, Svalbard) in terms of priority compounds, sampling schedule as well as analytical methods.

The POP concentration levels found in Antarctica were considerably lower than Arctic atmospheric background concentrations. Similar to observations for Arctic samples, HCB is the predominant POP compound, with levels of around $22 \mathrm{pg} \mathrm{m}^{-3}$ throughout the entire monitoring period. In general, the following concentration distribution was found for the Troll samples analyzed: HCB $>$ Sum $\mathrm{HCH}>$ Sum PCB $>$ Sum DDT $>$ Sum chlordanes.

Atmospheric long-range transport was identified as a major contamination source for POPs in Antarctic environments. Several long-range transport events with elevated levels of pesticides and/or compounds with industrial sources were identified based on retroplume calculations with a Lagrangian particle dispersion model (FLEXPART).
\end{abstract}

\section{Introduction}

Polar regions are considered today as important sentinels for global environmental processes for many scientific disciplines involved in environmental research. Polar locations are still characterized by minimum anthropogenic presence and, thus, are suitable regions for comprehensive baseline studies, including global circulation systems, hemispheric transport of anthropogenic pollution, radiation as well as cryosphere-related polar research (ACIA, 2005). Furthermore, the physico-chemical mechanisms controlling release, hemispheric transport, distribution and deposition of target contaminants can be examined in great detail with the help of long-term monitoring of pollutants (Ma et al., 2011; AMAP, 2009). Long-term atmospheric pollution monitoring in the polar regions is today considered a valuable and versatile scientific tool for assessing anthropogenic influences on the environment as well as controlling international regulation measures (Kallenborn and Berg, 2009; UNEP, 2011; Hung et al., 2010).

The current comprehensive Arctic long-term atmospheric POP-monitoring programs, in particular at the Zeppelin station and the Canadian Alert research station, have proved impressively the importance of these national commitments for the continuous operation of long-term atmospheric monitoring of persistent organic pollutants (POPs). They are considered as the central scientific basis for the empirical investigation of atmospheric transport and distribution processes (Dutchak and Zuber, 2010; UNEP, 2008; Aas et al., 2008) and are important for the evaluation of models simulating global distribution processes (Wania, 2003; Wania and 
Mackay, 1999). In combination with meteorological modeling, the continuous monitoring also reveals atmospheric long-range transport events as well as potential source regions, where regulative measures may be appropriate when international mitigation strategies are assessed. This information is today an important resource for the global POP regulations in order to provide the scientific basis for appropriate measures for global restriction of POP usage and distribution (Rodan et al., 1999; Clapp, 2003). The Arctic monitoring data are continuously reported to regional and international monitoring programs such as the Arctic Monitoring and Assessment Programme (AMAP), United Nations Economic Commission for Europe, European Monitoring and Evaluation Programme (UNECE-EMEP), Global Atmospheric Watch (GAW) and others (Holoubek et al., 2001). Thus, the experience with the past $20 \mathrm{yr}$ of monitoring in the Arctic has proved that this type of data is urgently required for a scientifically sound evaluation of the hemispherical transport and fate of legacy POPs and emerging so-called new POPs.

Until today, the establishment of long-term continuous atmospheric monitoring of POPs in Antarctica has been seriously hampered by political, economic and logistical restrictions (e.g., remoteness and cost-intensive logistics). During the past two decades, several campaign-based studies on short-term (only few) atmospheric monitoring of POPs in Antarctica have been reported in the literature (Kallenborn et al., 1995; Dickhut et al., 2005; Gambaro et al., 2005; Xie et al., 2011a, b; Möller et al., 2011; Kallenborn et al., 1998). Thus, only scattered scientific information has been available for the evaluation of atmospheric long-range transport of POPs in the high-latitude Southern Hemisphere and in particular for the Antarctic continent. The above-mentioned earlier studies indicated that potential primary sources (agriculture, industrial releases, etc.) in the Southern Hemisphere contribute to the POP levels in the Antarctic atmosphere. Nevertheless, due to the remoteness of Antarctica and few potential industrial sources in the Southern Hemisphere, levels of POPs have been previously considered as extremely low much lower than in the Arctic. However, Antarctica attracts more and more scientific interest as a location for pollutant research. Studies on potential local contamination issues in Antarctic environments reveal clearly that the anthropogenic impact on Antarctic pollution levels is not negligible despite considerable international efforts to minimize this human impact by means of international regulations, bans and restrictions (SCAR: Scientific Committee on Antarctic Research; GOSEAC: SCAR Group of Specialists on Environmental Affairs and Conservation; etc.).

Therefore, in 2007 the Norwegian Institute for Air Research (NILU) in collaboration with the Norwegian Polar Institute (NPI) initiated the first long-term atmospheric monitoring program for selected legacy POPs at the Antarctic Troll station (Dronning Maud Land, Antarctica). The POP atmospheric monitoring is building upon long scientific expe- rience with similar Arctic atmospheric monitoring programs handled and overseen by NILU since 1989. The atmospheric POP monitoring at Troll is coordinated closely with the similar monitoring program at the Arctic monitoring station on the Zeppelin mountain (Ny-Ålesund, Svalbard) in terms of sampling schedule, sampling and analytical quantification methods, as well as priority target POPs. This harmonization is important for data comparability and also for investigation of global transport patterns including potential interhemispherical POP distribution characteristics. The quantitative trace analyses of legacy POPs performed for the first four years of the still-ongoing monitoring program as weekly sampling (2007-2010) form the scientific basis for this study.

\section{Methods}

\subsection{Sampling location}

POP sampling was performed at the Troll Atmospheric Observatory, managed from the Norwegian Troll station (TRS; Dronning Maud Land, also known as Queen Maud Land, Antarctica), located at $72^{\circ} 01^{\prime} \mathrm{S}, 2^{\circ} 32^{\prime} \mathrm{E}$, at $1270 \mathrm{~m}$ a.s.l. in the Nunatak area of Jutulsessen glacier, about $235 \mathrm{~km}$ south from the Antarctic coast (Fig. 1). Its closest neighbor stations are the South African SANAE IV station, $190 \mathrm{~km}$ west-northwest, and the German Neumeyer station, $420 \mathrm{~km}$ east-northeast of TRS. TRS is situated on snow-free bedrock and accessible by air transport during Antarctic summer, facilitated by a blue-ice airfield on the glacier $7 \mathrm{~km}$ north of the main station. In June 2003, the Norwegian Ministry of the Environment decided to upgrade an existing summer research station and provide it with a runway for airplanes (the Troll Airfield), enabling year-round operation. The new station was officially opened in 2005, and a comprehensive atmospheric monitoring program was established including pollutant monitoring in 2006/2007 (e.g., POPs). Data from the first four years of continuous air sampling for POP monitoring are presented here.

\subsection{Sample collection}

Samples were collected from February 2007 until December 2010 on a weekly basis. For the monitoring, continuous integrated weekly (7-day) samples were collected with a flow rate of $10-15 \mathrm{~m}^{3} \mathrm{~h}^{-1}$, resulting in sample volumes between 2200 and $2500 \mathrm{~m}^{3}$. A commercially available high-volume air sampling device (DHA-80, DIGITEL, Hegenau, CH) for separate particle and gas phase collection was used for the monitoring of POPs. The gas phase was collected on precleaned polyurethane foam plugs (PUF), whereas the particle phase was collected on glass fiber filters (GFF; $10 \mathrm{~cm}$ i.d., cut-off $50 \mu \mathrm{m}$, Schleicher-Schuell, Dassel, GER). Gas and particle phase samples were collected simultaneously. Flow-rate and sampling conditions were digitally monitored and documented (e.g., power failures, etc.) as an integrated 
part of the sampling and quality control procedure. Sector controlled sampling was performed where air masses passing over the main research station were avoided by interrupting the sample collection in order to minimize the potential for local contamination.

\subsection{Sample storage}

After the sampling was completed, the exposed filters (GFF and PUF) were sealed in a gas-tight container for storage and transport to NILU's laboratory for further processing and quantification. No manual treatment/exposure is required prior to analysis of the filters. In addition, extensive numbers of field and transport blank samples followed the yearly sample batch in order to control potential contamination risks (as a part of the extensive quality control procedure of the NILU monitoring program). All exposed filters were registered and stored frozen $\left(-20^{\circ}\right)$ prior to analysis and quantification. The yearly sample set was shipped on the first flight every austral summer (November) to the analytical laboratory in Norway by combined ship and air freight transport.

\subsection{Sample preparation}

The sample preparation method was optimized based on an earlier-described method (Kallenborn et al., 2006). Details on the preparation methods are given in the Appendix of the paper. All solvents, adsorbents and gases used were of the highest quality available, well suited and selected for ultratrace analysis. Solvents and adsorbents were purchased from Merck (Spurenanalyse quality, Darmstadt, GER); all gases were provided by Hydro $\left(\mathrm{N}_{2}\right.$ and $\mathrm{He}, 6.0$ quality, Porsgrunn, NO).

All samples were Soxhlet extracted for $12 \mathrm{~h}$ with $n$ hexane/acetone $(50: 50, v: v)$. An amount of $10 \mathrm{ng}$ of ${ }^{13} \mathrm{C}$ labeled internal standards (IST) for all congener and isomer groups analyzed was added prior to extraction (for details see Appendix A). The GFF and PUF extracts were unified after extraction. Volume reduction to ca. $500 \mu \mathrm{L}$ was performed on a Turbovap (Caliper-Zymark, Hopkinton, MA, USA). After volume reduction, the extract was transferred to a $15 \mathrm{~cm}$ glass column (with stop cock) filled with precleaned and preconditioned Silica ( $2 \%$-w water) and a top layer of precleaned sodium sulfate for cleanup. After clean-up, the volume of the eluate was reduced to $500 \mu \mathrm{L}$ (Turbovap) and further reduced to $100 \mu \mathrm{L}$ under a gentle $\mathrm{N}_{2}$ stream. Before quantitative analysis, $10 \mathrm{ng}$ of unlabeled tetrachloronaphthalene (TCN) was added as recovery standard (RecStd, Tables S1-S3).

\subsection{Quantitative analysis}

The same priority target analytes were chosen for the Troll POP monitoring as measured at the Zeppelin research station (Ny-Ålesund, Svalbard, Arctic) for the past $20 \mathrm{yr}$. In total, 32 PCB congeners and 13 organochlorine pesticides

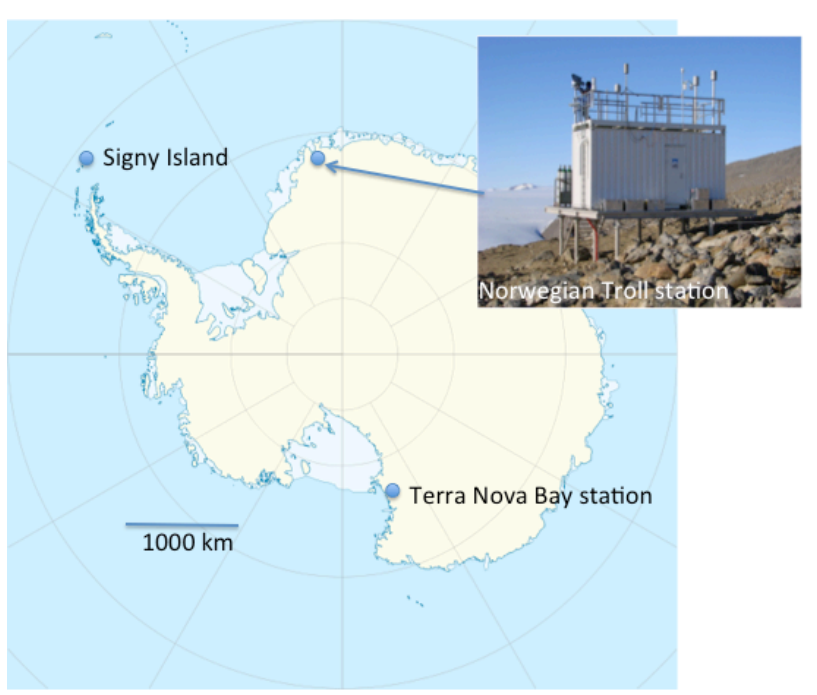

Fig. 1. The position of the Antarctic Troll Atmospheric observatory (Norwegian Troll research station, Dronning Maud Land, Antarctica). For comparison the British research station Signy Island and the Italian Terra Nova Bay station are shown. Map: courtesy of Wikipedia.

(OCPs) were quantified (for details on compounds and analytical methods, see Appendix A including Tables S1-S3).

After sample preparation, the eluates were quantitatively analyzed using high-resolution gas chromatography coupled to a high-resolution sector field mass spectrometer as detector (HRGC/HRMS). A 6890N Agilent gas chromatograph (Agilent, Palo Alto, CA, USA) was coupled to an Autospec Ultima sector field mass spectrometer (Waters, Milford, MA, USA). An aliquot of $2 \mu \mathrm{L}$ of the eluate was injected into the gas chromatograph in splitless mode $\left(280^{\circ} \mathrm{C}\right.$ and $2 \mathrm{~min}$ splitless time). The analyses were performed with maximum resolution (ca. 10 000) in Electron Impact (EI: PCBs, HCB, DDT derivatives) and Negative Ion Chemical Ionization mode (NICI: OCPs) for the respective compounds groups (for details on separation parameters including temperatures for injection and transfer line, temperature program, mass spectrometer parameters including reference and quantifier ions selected, and lock mass calibration, see Appendix A). Isotope dilution was applied for identification and quantification of the target chlorinated chemicals.

\subsection{Quality control}

The responsible technicians at the Troll research station followed detailed routines developed by NILU in order to avoid unwanted contamination during fieldwork. A set of field blank samples (1 field blank/month + transport blanks) was added to the field samples in order to control unintended contamination during storage and transport.

The analytical procedure used for the study was accompanied by a comprehensive quality control program based 
on the requirements of NILU's accreditation, according to EU standard EN 45001. The instrument limit of detection (LOD) was determined by calculating the signal-to-noise ratio $(S / N)>3$ for solvent blanks (using $n$-hexane). Extensive field and laboratory blank values were analyzed in order to monitor and control possible contamination during sample transport and laboratory work. No evidence for contamination during sample processing was found for the data presented here (no elevated values in field and laboratory blanks). Based upon average blank concentrations (for both laboratory and field blanks) the limit of quantification (LOQ) was calculated for all compounds with $\mathrm{LOQ}=$ average blank value plus 3 standard deviations (STDev) of the blank concentrations.

All samples within the range $L O Q>x>$ LOD are considered to have high uncertainties and reported $<$ LOQ (Table S8). All raw data are openly accessible from the NILU database (http://ebas.nilu.no) for thorough examinations. However, all original data are also listed in Appendix B (Table S7). All values below LOD were excluded from further statistical treatment (treated as not detected (n.d.)).

\subsection{Transport model calculations}

To relate measured concentrations to transport from potential source regions, 3-hourly backward simulations from the Troll station were made with the Lagrangian particle dispersion model FLEXPART (Kallenborn et al., 2006; Stohl and Sodemann, 2010) for the entire measurement period (see http://zardoz.nilu.no/ andreas/BACKWARD_ PRODUCTS/STATIONS/TROLL/). FLEXPART was driven with 3-hourly operational meteorological data from the European Centre for Medium-Range Weather Forecasts with $1^{\circ} \times 1^{\circ}$ resolution. During every $3 \mathrm{~h}$ interval, 60000 particles were released at the measurement point and followed backward for 20 days to calculate emission sensitivity $(S)$ on a $1^{\circ} \times 1^{\circ}$ grid, under the assumption that removal processes can be neglected. $S$ (in units of $\mathrm{s} \mathrm{kg}^{-1}$ ) in a particular grid cell is proportional to the particle residence time in that cell and measures the simulated mixing ratio at the receptor that a source of unit strength $\left(1 \mathrm{~kg} \mathrm{~s}^{-1}\right)$ in the cell would produce. The $S$ distribution in a $100 \mathrm{~m}$ layer adjacent to the surface (so-called footprint layer) was used to characterize the potential influence from Southern Hemisphere potential POP surface sources during the 20 days preceding the 3 -hourly particle release period. For the purpose of this paper, model results were averaged for the periods when POP samples were taken.

\section{Results and discussions}

\subsection{Hexachlorobenzene (HCB)}

Hexachlorobenzene (HCB; CAS No. 118-74-1) was used as fungicide. Currently HCB is predominantly released as an industrial by-product from various chemical processes. HCB was identified as the most abundant target contaminant in this study.

\subsection{Polychlorinated biphenyls (PCB)}

PCB (CAS No. 1336-36-3) is a technical mixture consisting of 209 different congeners with 1 to 10 chlorine atoms attached to a biphenyl molecular structure. PCB has been used in a variety of technical applications (Breivik et al., 2002). Of the total of 32 PCB congeners analyzed, only 14 congeners were quantified in seven samples between February 2008 and September 2007. Although PCBs were identified in all Troll air samples, due to elevated blank levels measured (Table S7), for most of the samples concentrations below the limit of quantification (LOQ) were determined. Therefore, no in-depth pattern elucidation for PCBs was performed in this study. Based upon this information, possible local contamination is assumed. Therefore, before the 2013 sampling period, the station was moved to a more remote location in the vicinity of the station (C. R. Lunder, personal communication, NILU, 2013).

As a general feature, in six samples, PCB 47 was found to be the most abundant congener $(<\mathrm{LOQ}$, between 0.09 $1.54 \mathrm{pg} \mathrm{m}^{-3}$ ). The congerers PCB 28, 33, 47 and 52 were found in all seven samples above LOQ. The seven samples with quantified PCB levels (> LOQ) are listed in Table 1.

The low PCB concentrations measured at Troll, relative to what has been reported for the Arctic (Hung et al., 2010), could be expected as only an estimated $3 \%$ of the historical use of PCBs took place in the Southern Hemisphere according to a global inventory of global PCB production and use (Breivik et al., 2002). For the countries of Chile and Argentina, the estimated historical use of total PCBs is 1270 and 7200 tons, respectively, which translates into $0.1 \%$ and $0.5 \%$ of the global historical production, although these numbers are affected by significant uncertainties (Breivik et al., 2002). For comparison, the compound specific limit of quantification (LOQ) values can be found in the Supplement (Table S7).

\subsection{Chlorinated pesticides}

A representative group of OCPs was selected as target analytes for the Troll monitoring program (12 compounds). All of the here-selected OCP are target chemicals for the global monitoring plan of the UNEP (United Nations Environmental Programme) Stockholm Convention for the global regulation of POPs. The $\alpha$ - and $\gamma$-hexachlorocyclohexane $(\mathrm{HCH})$, four chlordane-related cyclodiene pesticides (trans, cis-chlordane and trans-, cis-nonachlor), as well as the six major constituents of the DDT group (o, $p^{\prime}-p, p^{\prime}$-DDT, DDE, DDD) were analyzed (see Table S6).

Although considerable concentration variations were identified for the entire data set, several features were found 
Table 1. PCB concentrations in Troll air samples (2007-2010). The concentration levels are given in [pg m ${ }^{-3}$ ].

\begin{tabular}{|c|c|c|c|c|c|c|c|c|}
\hline \multirow[t]{2}{*}{ Structure } & \multirow[t]{2}{*}{$\mathrm{PCB}$} & \multicolumn{7}{|c|}{ Sampling start (date of the weekly sampling period); conc. $\left[\mathrm{pg} \mathrm{m}^{-3}\right.$ ] } \\
\hline & & $7 / 22 / 08$ & $11 / 24 / 08$ & $3 / 2 / 09$ & $5 / 18 / 09$ & $7 / 5 / 10$ & $8 / 2 / 10$ & $9 / 6 / 10$ \\
\hline 2,4,4'-TriCB & 28 & 0.25 & 0.16 & 0.13 & 0.21 & 0.18 & 0.45 & 0.15 \\
\hline $2,4^{\prime}, 5-\operatorname{TriCB}$ & 31 & 0.23 & 0.22 & $<\mathrm{LOQ}$ & 0.21 & 0.19 & 0.48 & $<\mathrm{LOQ}$ \\
\hline $2^{\prime}, 3,4-$ TriCB & 33 & 0.18 & 0.11 & 0.10 & 0.15 & 0.13 & 0.35 & 0.11 \\
\hline $3,4,4^{\prime}-$ TriCB & 37 & 0.04 & 0.02 & 0.01 & 0.02 & 0.01 & 0.06 & 0.02 \\
\hline $2,2^{\prime}, 4,4^{\prime}-$ TetraCB & 47 & $<\mathrm{LOQ}$ & 0.14 & 0.29 & 0.80 & 0.56 & 1.54 & 0.47 \\
\hline 2,2',5,5'-TetraCB & 52 & 0.18 & 0.17 & 0.15 & 0.22 & 0.19 & 0.45 & 0.17 \\
\hline $2,3^{\prime}, 4,4^{\prime}-$ TetraCB & 66 & 0.04 & 0.03 & $<\mathrm{LOQ}$ & $<\mathrm{LOQ}$ & $<\mathrm{LOQ}$ & 0.07 & $<\mathrm{LOQ}$ \\
\hline 2,4,4',5-TetraCB & 74 & 0.03 & $<\mathrm{LOQ}$ & $<\mathrm{LOQ}$ & $<\mathrm{LOQ}$ & $<\mathrm{LOQ}$ & 0.04 & $<\mathrm{LOQ}$ \\
\hline 2,2',4,4',5-PentaCB & 99 & 0.11 & 0.04 & $<\mathrm{LOQ}$ & $<\mathrm{LOQ}$ & $<\mathrm{LOQ}$ & $<\mathrm{LOQ}$ & $<\mathrm{LOQ}$ \\
\hline 2,2',4,5,5'-PentaCB & 101 & $<\mathrm{LOQ}$ & $<\mathrm{LOQ}$ & 0.10 & 0.07 & 0.07 & 0.24 & 0.09 \\
\hline 2,3,3',4,4'-PentaCB & 105 & $<\mathrm{LOQ}$ & $<\mathrm{LOQ}$ & $<\mathrm{LOQ}$ & $<\mathrm{LOQ}$ & $<\mathrm{LOQ}$ & $<\mathrm{LOQ}$ & $<\mathrm{LOQ}$ \\
\hline 2,3,4,4',5-PentaCB & 114 & 0.02 & 0.02 & $<\mathrm{LOQ}$ & $<\mathrm{LOQ}$ & $<\mathrm{LOQ}$ & $<\mathrm{LOQ}$ & $<\mathrm{LOQ}$ \\
\hline
\end{tabular}

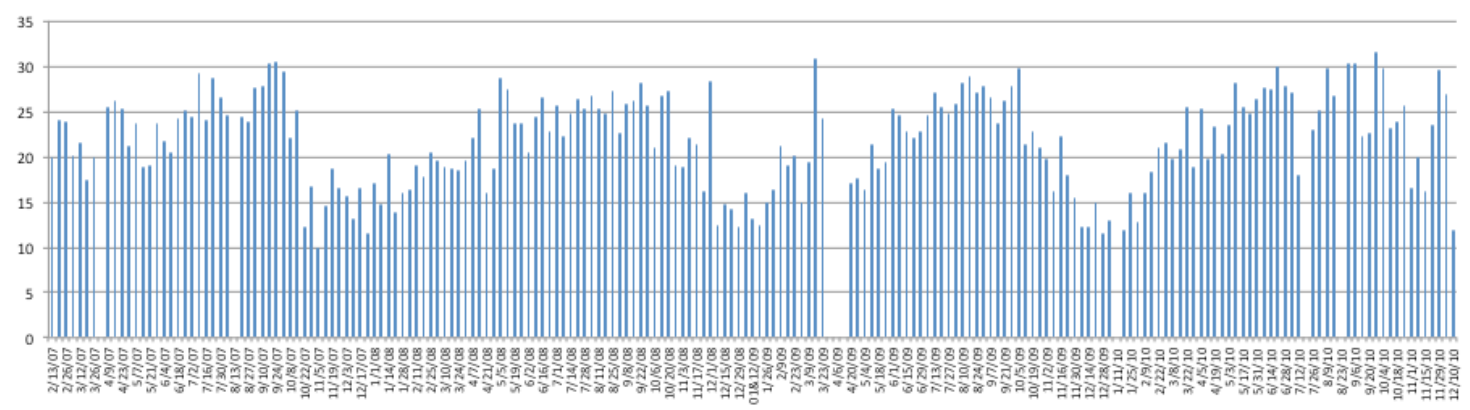

Fig. 2. Concentration distribution of hexachlorobenzene (HCB) in atmospheric samples from Troll (Antarctica); period: 2007-2010; $x$-axis: sampling start date; $\mathrm{y}$-axis: conc. $\left[\mathrm{pg} \mathrm{m}^{-3}\right.$ ].

characteristic for the POP distribution in the Troll atmospheric samples. HCB was the POP with the highest concentrations, followed by the sums of $\mathrm{HCHs}$, PCBs, DDTs and chlordanes $(\mathrm{HCB}>\mathrm{Sum} \mathrm{HCH}>\mathrm{Sum} \mathrm{PCB}>\mathrm{Sum}$ DDT $>$ Sum chlordanes). For single compounds other than $\mathrm{HCB}, a-\mathrm{HCH}$ and $p, p^{\prime}-\mathrm{DDE}$ were the most prominent constituents.

HCB was identified as the major POP in the Antarctic air samples with concentration levels varying around $22 \mathrm{pg} \mathrm{m}^{-3}$ (average concentration) for the entire monitoring period. HCB was positively identified in all 196 samples quantified. No temporal trend could be established for HCB at Troll during the $4 \mathrm{yr}$ measuring period. However, in contrast to the Arctic data from the Zeppelin station (Hung et al., 2010), a characteristic seasonal pattern was found for Troll air samples, with highest levels during the austral winter period (week 25-45) and lower levels during the austral summer seasons (Fig. 2). This is likely related to seasonally varying atmospheric transport from Australia, Africa and South America, which is much more effective in winter than in summer (Gambaro et al., 2005; Kallenborn et al., 1998). However, increased $\mathrm{OH}$ radical concentrations in combina- tion with higher ambient temperatures may also lead to increased transformation and, thus, lower HCB air concentrations during the summer season. The HCB concentrations found at Troll station are generally 3-4 times lower than those observed at the Zeppelin station (Svalbard, Norwegian Arctic). The here observed seasonal pattern for HCB might be slightly overestimated due to potential breakthrough on the PUF filters caused by the high sample volumes collected. However, due to the overall low ambient temperatures during the monitoring period (average $-20^{\circ} \mathrm{C}$ in winter and $-8^{\circ} \mathrm{C}$ in summer) this is considered a minor problem only at Troll.

The most abundant OCP compound in Troll atmospheric samples was $\alpha-\mathrm{HCH}$, with concentrations varying between 0.02 and $0.46 \mathrm{pg} \mathrm{m}^{-3}$. The $\alpha-\mathrm{HCH}$ isomer was identified in all 196 samples analyzed. As also shown for the Arctic Zeppelin station (AMAP, 2009; Hung et al., 2010; Kallenborn and Berg, 2006; Ma et al., 2011), $\alpha$-HCH had higher concentrations in Troll air samples than the related $\gamma-\mathrm{HCH}$ isomer $(\alpha-/ \gamma-\mathrm{HCH}$ ratio: $2-24)$ in all Troll air samples. For the $\mathrm{HCH}$ isomers, $\alpha-\mathrm{HCH}$ was usually 3-4 times more highly concentrated than the sister isomer, $\gamma-\mathrm{HCH}$. Thus a $\alpha-\gamma-\mathrm{HCH}$ ratio in the range of $3-5$ is considered as an expected ratio 
indicating no unusually contaminated air masses. Variations between 2 and 5 were commonly observed in the Troll air samples.

For both the DDT group (dichlorodiphenyltrichloroethane derivatives) and cyclodiene pesticides (chlordane-related compounds) very low levels were detected in the Troll air samples. The chlordane compound cis-chlordane (cisCD) was the most abundant of those compounds (identified in 162 samples; concentration levels: $\left.0.02-0.20 \mathrm{pg} \mathrm{m}^{-3}\right)$, whereas for $p, p$ - DDE higher concentration levels were found (identified in 156 samples; concentration levels: 0.02$0.42 \mathrm{pg} \mathrm{m}^{-3}$ ). The ratio $p, p^{\prime}-\mathrm{DDE} / p, p^{\prime}-\mathrm{DDT}$ is often used as indication for potential contribution of fresh application of technical DDT to the measured DDT contamination in atmospheric samples. A ratio close to 1 will indicate fresh DDT application, whereas ratios $>3$ are considered as indication of predominant influence of weathered DDT from secondary diffusive sources. The $p, p^{\prime}$-DDE/p,p'-DDT ratios for 2007 presented in Fig. 3 revealed several episodes where values close to and even below 1 indicate influences of fresh technical DDT (Fig. 3). Therefore the direct transport of newly applied DDT for malaria prevention in tropical regions is still considered a significant source of DDT levels in the atmosphere over the Southern Hemisphere, even in Antarctica.

However, since DDT is considered an important byproduct during dicofol production, a high proportion of $o, p$ DDT in air samples may also indicate dicofol application in the respective source regions. For the Troll air samples, in 35 samples $p, p^{\prime}$-DDT/ o, $p$ '-DDT ratios between 1 and 6 could be established. However, in technical dicofol the $o, p^{\prime}$-DDT is usually 3-7 times higher in concentration than the $p, p^{\prime}$-DDT (Qui et al., 2005). Thus, a clear indication of dicofol application as a contamination source could not be confirmed for the Troll monitoring data.

The long-range atmospheric transport of POPs from global source region towards Polar regions is limited by atmospheric degradation/transformation and deposition (Beyer et al., 2003). However, atmospheric reaction is anticipated to be of relatively minor significance in the Antarctic, due to low concentrations of $\mathrm{OH}$ radicals (Lelieveld et al., 2004) combined with low air temperatures (Webster et al., 1998). The long-range atmospheric transport potential among the individual compounds selected may be further discriminated by their potential to be scavenged by aerosols, rain and snow (Lei and Wania, 2004). To illustrate this, we have estimated the percentage of the respective compounds sorbed onto aerosols from $5^{\circ} \mathrm{C}$ to $-50^{\circ} \mathrm{C}$, which covers the observed temperature range $\left(\sim 0{ }^{\circ} \mathrm{C}\right.$ to $\left.-40^{\circ} \mathrm{C}\right)$ previously reported at Troll (Hansen et al., 2009). At $-20^{\circ} \mathrm{C}, \mathrm{HCB}, \mathrm{HCHs}$ and PCBs 28, 52 and 101 are predicted to dominate in the gaseous state among the substances included, which mirrors the overall results of the measurements. There are also some notable differences predicted within groups of substances in terms of gas/particle partitioning. At $-15^{\circ} \mathrm{C}, 87 \%$ of $p, p^{\prime}-$ $\mathrm{DDD}, 60 \%$ of $p, p^{\prime}$-DDT and $29 \%$ of $p, p^{\prime}-\mathrm{DDE}$ is predicted

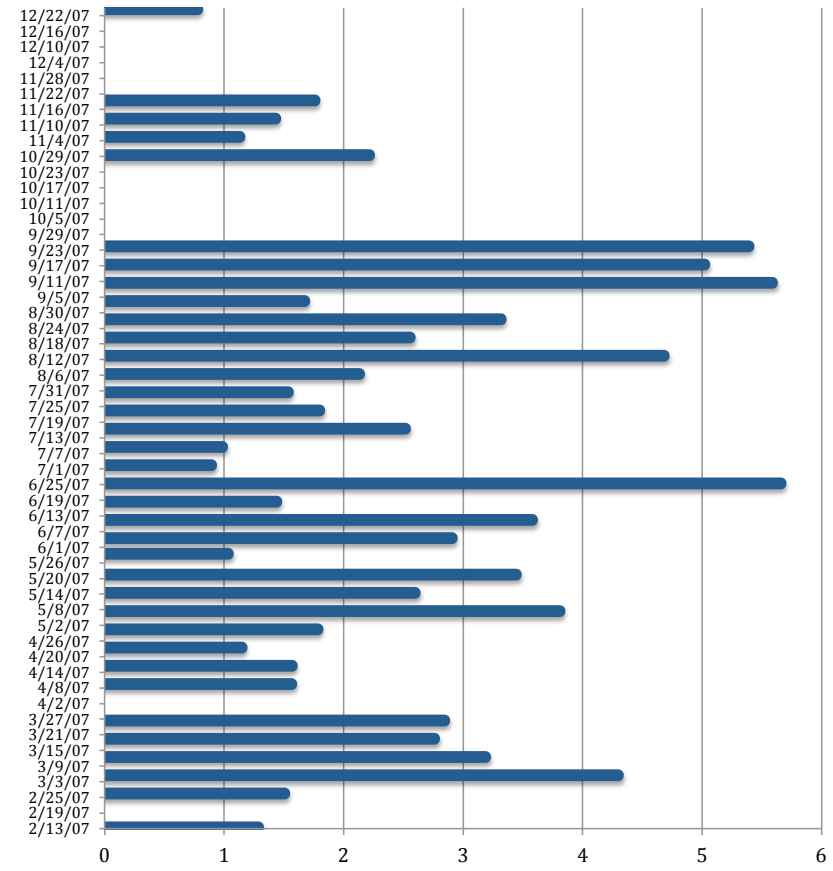

Fig. 3. $p, p^{\prime}-\mathrm{DDE} / \mathrm{p}, p^{\prime}$-DDT ratios (x-axis) for weekly atmospheric samples (y-axis: sampling start date) from the Troll station (Antarctica); $\mathrm{x}$-axis = conc./conc., $\mathrm{y}$-axis: starting date (sampling year 2007).

to be sorbed onto aerosols, which could help to explain why $p, p$ '-DDE appears to be occasionally elevated at Troll. Thus, $p, p$ '-DDE is associated more to the vapor phase, whereas the other isomers are expected to be deposited more rapidly by particle-related deposition processes.

For other related substances which were predominantly present in the gas phase almost through the entire temperature range, such as $\mathrm{HCHs}$, differences in rain or snow scavenging may be more relevant to elucidate potential differences in atmospheric deposition. While $\gamma-\mathrm{HCH}$ may be more easily washed out by rain than $\alpha-\mathrm{HCH}$ (Lei and Wania, 2004), any potential differences in snow scavenging between these two isomers are more difficult to predict (Lei and Wania, 2004). For the one-week sampling period at Troll the measured air concentrations are often very low or close to detection limits. Therefore one may argue that any potential long-rang atmospheric transport events are best identified by elevated air concentrations of more volatile substances, while samples showing occasionally elevated air concentrations of less volatile substances alone may rather indicate influence of local sources within the Antarctic.

For HCHs direct applications of technical HCH or emissions from technical $\mathrm{HCH}$ waste deposited in southern African or South American regions may also directly contribute to the observed elevated levels. 


\subsection{Atmospheric long-range transport}

For the elucidation of potential contamination sources, also general pattern differences were compared. For the identification of different emission sources, the concentrations of a typical agrochemical $(\gamma-\mathrm{HCH})$ were plotted against the concentrations of an industrial chemical (HCB); see Fig. 4. HCB is the most abundant contaminant in Troll air samples, with levels between 10 and $80 \mathrm{pg} \mathrm{m}^{-3}$, whereas $\gamma-\mathrm{HCH}$ is found in concentrations of around 0.1 to $0.5 \mathrm{pg} \mathrm{m}^{-3}$. An unusually high concentration of at least one of the compounds indicates atmospheric transport of contaminated air mass to the Troll station. Relatively high concentrations of $\gamma-\mathrm{HCH}$ are found for samples taken during weeks 27/2009 (sampling start: 6/29/09) and 33/2010 (sampling start: 8/9/10); see Fig. 4.

Figure 5 shows the corresponding footprint emission sensitivity obtained from the FLEXPART 20-day backward simulation for the period when this air sample was taken. The emission sensitivity over Chile and Argentina for this sample is enhanced by nearly an order of magnitude compared to the seasonal-mean 20-day backward footprint emission sensitivity, indicating unusually strong transport from these potential source regions to the Troll station.

In Fig. 4, significantly elevated levels for the agrochemical $\gamma$-HCH were observed during week 27/2009 (sampling start: 6/29/09). For this week, the FLEXPART calculations show that high emission sensitivity values extend much further north over Africa (lower part, Fig. 5) than for seasonally averaged transport (upper part, Fig. 5). The emission sensitivity over southern Africa is nearly one order of magnitude higher than in the seasonal mean, indicating much stronger transport from southern Africa to Troll than normally. Again, the increase in emission sensitivity is consistent with the measured $\gamma-\mathrm{HCH}$ concentration enhancement. According to a recent review by Vijgen et al. (2011), Lindane ${ }^{\circledR}$ (> 99\% $\gamma$ $\mathrm{HCH}$ ), as well as the technical $\mathrm{HCH}$ mixture, was produced in South Africa in significant amounts. It is also reported that about $70000 \mathrm{t}$ of $\mathrm{HCH}$ waste isomers are still stored and/or deposited in this country.

Also several other samples were identified with elevated contribution of either HCB and/or $\gamma-\mathrm{HCH}$ (Fig. 4); for several of those, enhanced transport from continental source regions (mainly from South America) can also be seen in the FLEXPART calculations. Thus, the atmospheric long-range transport of polluted air masses is considered as the main source for the legacy POPs monitored at Troll.

\subsection{Comparison with historical data}

Previously, only a few campaign-based data sets of atmospheric POP concentrations were collected with active highvolume sampling devices in Antarctica. An 11-week sampling campaign was performed in 1993 (October-December) at the Italian research station Terra Nova Bay, now Zuchelli station (Victoria Land; Kallenborn et al., 1995). As a follow- up of the 1993 sampling program and in cooperation with the British Antarctic Survey (BAS), NILU performed a first year-round measuring campaign for POPs in Antarctic air at the British research station in Signy Island (South Orkney Islands) in the period 1994-1995 (Kallenborn et al., 1998). During both campaigns similar priority compounds were quantified and analytical methods were used as studied in this paper. HCB and HCHs were also measured during a process study for air/water exchange of selected chlorinated pesticides in the Ross Sea region at Terra Nova Bay in 2003 (nine samples; Cincinelli et al., 2009). Finally, a campaign-based study on PCBs in Terra Nova Bay air samples was published a few years ago (Gambaro et al., 2005). The here-discussed results are summarized for comparison in Table 2. For almost all compounds analyzed, considerable concentration reductions are registered compared to the above-mentioned previous atmospheric POP measurement campaigns. The only exception is HCB (Table 2), for which similar concentration levels were found as registered in the 1993 sampling campaign at Terra Nova Bay (Victoria Land; Kallenborn et al., 1995). The average levels measured in Terra Nova Bay air from 2003 (Cincinelli et al., 2009) are based on nine weekly summer samples only (December to March 2003). A factor of 2 lower concentrations is, thus, considered as well within the range of variations compared to the 2010 whole-year sampling set from Troll, given the observed seasonal variation with a summer minimum (Fig. 2).

In the early studies (sampling 1993, 1995; Kallenborn et al., 1995, 1998) a slight predominance of $\gamma$-HCH was identified in atmospheric samples. However, in the data set presented here, $\alpha-\mathrm{HCH}$ was the most abundant $\mathrm{HCH}$ isomer analyzed in all samples. The most obvious reason for this pattern shift along with significant overall concentration reductions of about a factor 100 compared to the 1993 and 1995 campaigns (see Table 2) may be sought in the national ban of Lindane ${ }^{\circledR}(>99 \% \gamma-\mathrm{HCH})$ in Asian countries (i.e., China and India) around the year 2000. However, other potential reasons may contribute (including increased emissions from $\gamma$-HCH deposited in South Africa previously mentioned) and should thus be included in the current discussion on potential $\gamma$-HCH sources for Antarctic atmospheric samples.

In order to gain a better scientific understanding on global distribution processes for anthropogenic pollutants, the establishment of a global atmospheric monitoring network is considered an important tool both for regulators and environmental scientists (AMAP, 2009; Kallenborn and Berg, 2004; Kallenborn et al., 2012). Therefore regionally based monitoring programs are encouraged to coordinate their monitoring priorities in order to establish global networks (UNEP, 2009). However, the first global effectiveness assessment of the POPs, the Stockholm Convention, revealed that most atmospheric POP-monitoring data (relevant for regulative purposes) is reported from the Northern Hemisphere. The longterm POP-monitoring networks in the Southern Hemisphere are not yet on the same levels of sophistication as compared 


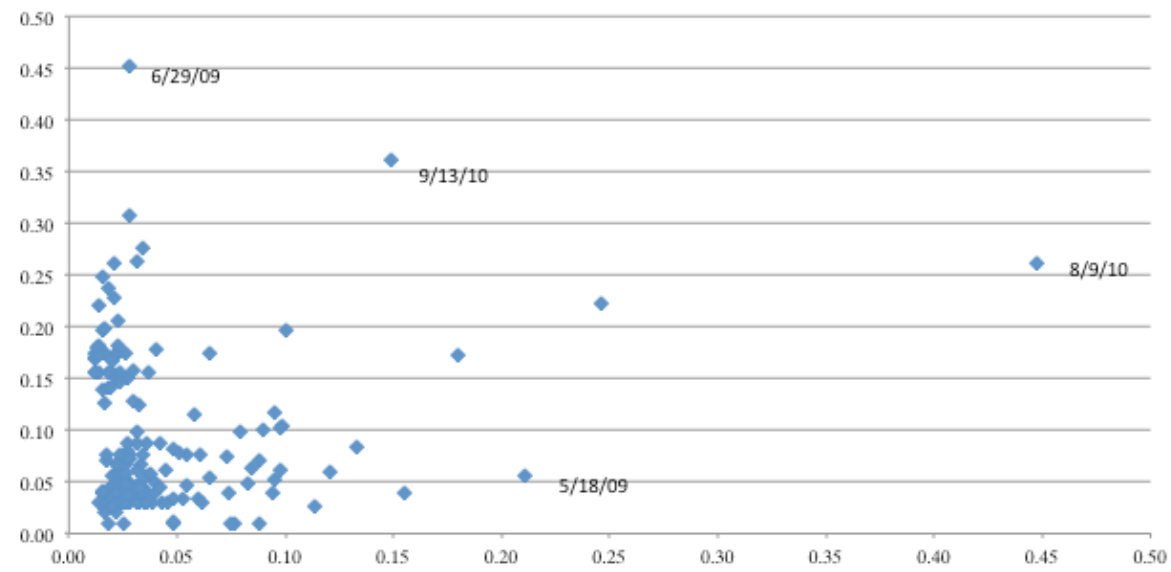

Fig. 4. Concentration comparison of HCB (y-axis) and $\gamma$-HCH (x-axis) in air samples from Troll (Antarctica: 2007-2010).
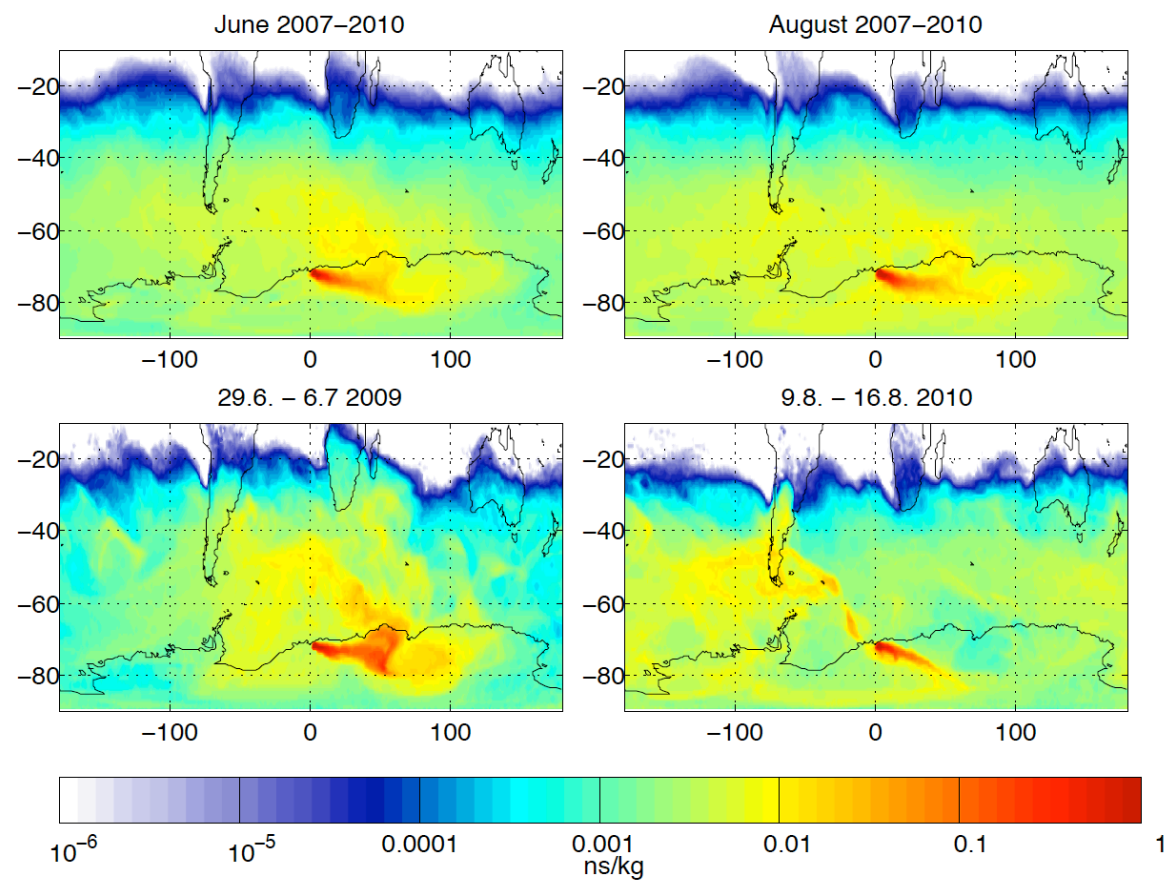

Fig. 5. Footprint emission sensitivities calculated with FLEXPART. Upper line: average monthly simulations (June and August) for the entire sampling period (2007-2010) as examples of the transport climatology for the respective months. Lower line: 20-day backward simulations for two weekly POP samples taken at Troll station during weeks 27/2009 (left) and 33/2010 (right).

with the northern networks (UNEP, 2009). The obvious differences in available monitoring infrastructure, cost for establishing and maintaining the infrastructure, expert support, national regulation programs and research funding priorities are considered an important reason for the still-large lack of atmospheric POP-monitoring data from the Southern Hemisphere and especially in Antarctica (compared to Arctic regions). Therefore, the here-presented POP monitoring and research study on POP distribution in Antarctic air will hopefully contribute significantly to the ongoing coordi- nated efforts for the continuous surveillance of priority POPs in Antarctica and, thus, help to understand the complex processes leading to the currently observed global distribution of this type of anthropogenic pollution.

\section{Conclusions}

The first long-term monitoring program for atmospheric transported persistent organic pollutants is presented. The monitoring program has been established (2007) at 
Table 2. Atmospheric POP distribution in Antarctic air; a comparison (concentration range in parenthesis).

\begin{tabular}{lllll}
\hline Compounds $\left[\mathrm{pg} \mathrm{m}^{-3}\right.$ ] & $\begin{array}{l}\text { Terra Nova Bay 1993; } \\
\text { (Kallenborn et al., } \\
\text { 1995; average conc.) }\end{array}$ & $\begin{array}{l}\text { Signy Island 1994- } \\
1995 \text { (average conc.), } \\
\text { Kallenborn et al. (1998) }\end{array}$ & $\begin{array}{l}\text { Terra Nova Bay 2005 } \\
\text { (average conc.), } \\
\text { Gambaro et al. (2005) }\end{array}$ & $\begin{array}{l}\text { Troll 2010 } \\
\text { (this study) }\end{array}$ \\
\hline HCB & 21 (n.d.-28) & - & $11.4(6-20)^{24}$ & 22.9 \\
Sum $\alpha-\& \gamma-\mathrm{HCH}$ & $13(5-20)$ & $27(3-33)$ & $0.8(0.3-1.2)^{24}$ & 0.2 \\
Sum $4 \mathrm{CD}^{\mathrm{a}}$ & 3.5 (n.d.-6) & $0.4(.004-0.9)$ & - & 0.1 \\
Sum 6 DDT & - & $0.2(0.07-0.4)$ & - & 0.03 \\
Sum PCB $^{\mathrm{c}}$ & 9 (n.d.-15) & $7(0.02-17)$ & $0.7(0.3-1.3)^{\mathrm{d}}$ & 0.5 \\
\hline
\end{tabular}

${ }^{\mathrm{a}}$ Sum trans/cis- chlordane and nonachlor; ${ }^{\mathrm{b}}$ Sum DDT $=p, p \%$, $p^{c}$-DDT, DDD, DDE; ${ }^{\mathrm{c}}$ Sum PCB, 18, 28/31, 52, 99, 101, 118, 149, 138, 153, 180; n.d. = not detected; ${ }^{\mathrm{d}}$ only gas phase compounds quantified.

the Norwegian Troll station (Dronning Maud Land). The concentrations found were considerably lower than the monitoring data measured in the Arctic illustrating the combination of remoteness and lack of potential local sources for Antarctic sampling sites. By combining modern modelling tools with pattern evaluation of available concentration data, several atmospheric long range transport events were identified and discussed here. The influence of the southern African continent for the transport of legacy organochlorine pesticides (i.e. HCHs) was confirmed in this study.

\section{Supplementary material related to this article is available online at: http://www.atmos-chem-phys.net/13/ 6983/2013/acp-13-6983-2013-supplement.zip.}

Acknowledgements. This work was financed through the Norwegian Climate and Pollution Agency (KLIF). Financial support from the Norwegian Antarctic Research Expeditions (NARE) was also received. FLEXPART modeling was supported by the Research Council of Norway in the framework of the CLIMSLIP project. We thank the year-round crews of the Norwegian Polar Institute (NPI) at the Antarctic Troll station for maintaining the sampling units and the competent sampling storage of the exposed samples as well as for shipping the samples to the NILU laboratory. The NILU laboratory team has performed well under rigorous sample preparation and analytical procedures according to comprehensive quality control requirements for ultra-trace analysis at the institute. Thanks to Hans Gundersen, Anders R. Borgen as well as Synnøve G. Trandem for quantitative analysis and the work in the laboratory. The NILU field team, but especially Jan H. Wasseng, is thanked for annual maintenance of the equipment at the Troll station and calibration of sampling units.

Edited by: R. Ebinghaus

\section{References}

Aas, W. and Breivik, K.: Heavy metals and POP measurements 2006. EMEP Cooperative Programme for monitoring of the Long-range transmission of air pollution in Europe, EMEP/CCCreport 4, 115 pp., 2008.

ACIA: Arctic Climate Impact Assessment, Cambridge University Press, 1042 pp., 2005.

AMAP: Arctic Pollution, Arctic Monitoring and Assessment Programme, 2009, Oslo. xi+83pp., 2009.

Armitage, J., Cousins, I., Buck, R. C., Prevedouros, K., Russel, M. H., MacLeod M., and Korzeniowski, S. H.: Modelling global-scale and transport of perfluorooctanoate emitted for direct sources, Environ. Sci. Technol., 40, 6969-6975, 2006.

Beyer, A., Wania, F., Gouin, T., Mackay, D., and Matthies, M.: Temperature dependence of the characteristic travel distance, Environ. Sci. Technol., 37, 766-771, 2003.

Breivik, K., Sweetman, A., Pacyna, J. M., and Jones, K. C.: Towards a global historical emission inventory for selected PCB congeners - a mass balance approach 1 Global production and consumption, Sci. Total Environ., 290, 181-198, 2002.

Cincinelli, A., Martinelli, T., Del Bubba, M., Lepri, L., Corsolini, S., Borghesi, N., King, M. D., and Dickhut, R. M.: Organochlorine pesticide air-water exchange and bioconcentration in krill in the Ross Sea, Environ. Poll., 157, 2153-2158, 2009.

Clapp, J. Transnational corporate interests and global environmental governance: negotiating rules for agricultural biotechnology and chemicals, Environ. Politics, 12, 1-23, 2003.

Dickhut, R. M., Cincinelli, A., Cochran, M., and Ducklow, H. W.: Atmospheric concentrations and air-water flux of organochlorine pesticides along the western Antarctic peninsula, Environ. Sci. Technol., 39, 465-470, 2005.

Dutchak, S. and Zuber, A. (Eds.): Hemispherical transport of air pollution 2010. Part C: Persistent organic pollution. Air Pollution Studies No. 19. Task Force on Hemispheric Transport of Air Pollution acting within the framework of the Convention on Long-range Transboundary Air Pollution, 256 pp., 2010.

Gambaro, A., Manodori, L., Zangrando, R., Cincinelli, A., Capodaglio, G., and Cescon, P.: Atmospheric PCB Concentrations at Terra Nova Bay, Antarctica, Environ. Sci. Technol., 39, 9406-9411, 2005.

Hansen, G., Aspmo, K., Berg, T., Edvardsen, K., Fiebig, M., Kallenborn, R., Lunder, C. R., Stebel, K., Schmidbauer, N., Solberg, S., Wasseng, J. H., and Yttri, K. E.: Atmospheric monitoring at the 
Norwegian Antarctic station Troll: Measurement programme and first results, Polar Res., 2, 353-363, 2009.

Holoubek, I., Ansorgova, A., Shatalov, V., Dutchak, S., and Kohoutek, J.: Regional background monitoring of PBT compounds, Environ. Sci. Pollut. Res., 8, 201-211, 2001.

Hung, H., Kallenborn, R., Breivik, K., Manø, S., BrorstrømLunden, E., Olafsdottir, K., Leppainen, S., Stern, G., Sverko, E., Fellin, P., and Skov, H.: Atmospheric Monitoring of Organic Pollutants in the Arctic under the Arctic Monitoring and Assessment Programme (AMAP): 1993-2006, Sci. Total Environ., 408, 2854-2873, 2010.

Kallenborn, R. and Berg, T.: Long-term atmospheric contaminant monitoring for the elucidation of airborne transport processes into Polar Regions, in: Arctic and Alpine Ecosystems and people in a changing environment, edited by: Ørbæk, J. B., Kallenborn, R., Tombre, I., Nøst-Hegseth, E., Falk-Petersen, S., and Hoel, A. H., Springer Verlag, 351-376, 2006.

Kallenborn, R., Oehme, M., and Schmidbauer, N.: Similarities and differences in Arctic and Antarctic air samples: Distribution of persistent and high volatile compounds in Arctic and Antarctic Air. Proceedings, Atti del $4^{\circ}$ Convegno Nazionale, Contaminazione Ambientale, Universita Ca' Foscari di Venezia, Programma Nazionale di Ricerche in Antartide, 1-8, 1995.

Kallenborn, R., Oehme, M., Wynn-Williams, D. D., Schlabach, M., and Harris, J.: Ambient air levels and atmospheric long-range transport of persistent organochlorines to Signy island, Antarctica, Sci. Total Environ., 220, 167-180, 1998.

Kallenborn, R., Christensen, G., Evenset A., Schlabach, M., and Stohl, A.: Atmospheric transport of persistent organic pollutants (POPs) to Bjørnøya (Bear island), J. Environ. Monitor., 9/10, 1082-1091, 2006.

Kallenborn, R., Reiersen, L. O., and Daae-Olseng, C.: Long-term atmospheric monitoring of persistent organic pollutants (POPs) in the Arctic: a versatile tool for regulators and environmental science studies, Atmos. Poll. Res., 3, 589-493, 2012.

Lei, Y. D. and Wania, F.: Is rain or snow a more efficient scavenger of organic chemicals?, Atmos. Environ., 38, 3557-3571, 2004.

Lelieveld, J., Dentener, F. J., Peters, W., and Krol, M. C.: On the role of hydroxyl radicals in the self-cleansing capacity of the troposphere, Atmos. Chem. Phys., 4, 2337-2344, doi:10.5194/acp4-2337-2004, 2004.

Ma, J., Hung, H., Tian, C., and Kallenborn, R.: Revolatilization of persistent organic pollutants in the Arctic induced by climate change, Nature Climate Change, 1, 255-260, 2011.

Möller, A., Xie, Z., Sturm, R., and Ebinghus, R.: Large-Scale distribution od Dechlorane Plus in air and seawater from the Arctic to Antarctica, Environ. Sci. Technol., 44, 8977-8982, 2011.
Qiu, X., Zhu, T., Yao, B., Hu, J., and Hu, S.: Contribution of dicofol to the current DDT pollution in China, Environ. Sci. Technol., 39, 4385-4390, 2005.

Rodan, B. D., Pennington, D. W., Eckley, N., and Boething R. S.: Screening of persistent organic pollutants: Techniques to provide the scientific basis for POPs criteria in international negotiations, Environ. Sci. Technol., 33, 3482-3488, 1999.

Stohl, A. and Sodemann, H.: Characteristics of atmospheric transport into the Antarctic troposphere, J. Geophys. Res., 115, D02305, doi:10.1029/2009JD012536, 2010.

Stohl, A., Hittenberger, M., and Wotawa, G.: Validation of the Lagrangian particle dispersion model FLEXPART against large scale tracer experiment data, Atmos. Environ., 32, 1998, 42454264, 1998.

Stohl, A., Forster, C., Frank, A., Seibert, P., and Wotawa, G.: Technical note: The Lagrangian particle dispersion model FLEXPART version 6.2, Atmos. Chem. Phys., 5, 2461-2474, doi:10.5194/acp-5-2461-2005, 2005.

UNEP: Global Monitoring Plan for Persistent Organic Pollutants. First Regional Monitoring Report, Western Europe and Other Groups (WEOG) Region, United Nations Environment Programme, 105 pp., 2008.

UNEP: Global monitoring plan for persistent organic pollutants. First regional monitoring report: Western European and other groups (region), Report, 106 pp., 2009.

UNEP: Climate Change and POPs: Predicting the impact, Report of the UNEP/AMAP expert group, 65 pp., 2011.

Vijgen, J., Abhilash, P. C., Li, Y. F., Lal, R., Forter, M., Torres, J., Singh, N., Yunus, M., Tian, C. G., Schaffer, A., and Weber, R.: Hexachlorocyclohexane $(\mathrm{HCH})$ as new Stockholm Convention POPs-a global perspective on the management of Lindane and its waste isomers, Environ. Sci. Pollut. Res., 18, 152-162, 2011.

Wania, F.: Assessing the potential of persistent organic chemicals for long-range transport and accumulation in polar regions, Environ. Sci. Technol., 37, 1344-1351, 2003.

Wania, F. and Mackay, D.: The evolution of mass balance models of persistent organic pollutant fate in the environment, Environ. Poll., 100, 223-240, 1999.

Webster, E., Mackay, D., and Wania, F.: Evaluating environmental persistence, Environ. Toxicol. Chem., 17, 2148-2158, 1998.

Xie, Z., Koch, B. P., Möller, A., Sturm, R., and Ebinghaus, R.: Transport and fate of hexachlorocyclohexanes in the oceanic air and surface seawater, Biogeosciences, 8, 2621-2633, doi:10.5194/bg-8-2621-2011, 2011a.

Xie, Z., Möller, A., Ahrens, L., Sturm, R., and Ebinghaus, R.: Brominated flame retardants in seawater and atmosphere of the Atlantic and the southern Ocean., Environ. Sci. Technol., 45, 1820-1826, 2011b. 